\title{
Role of Vamana Karma (Emesis) in Jeerna Vatika Pratishyaya (Chronic Rhinosinusitis) - A Case Study
}

\author{
Case Report
}

\section{Kunjal H Bhatt ${ }^{*}$, Hemang U Raghavani ${ }^{2}$, Kishor G Satani ${ }^{3}$, Haridra C Dave ${ }^{4}$}

\author{
1. Lecturer, Department of Shalakya Tantra, 2. Lecturer, Department of Panchkarama, \\ 3. Reader, Department of Basic principles, 4. Head of the Department, Depatment of Shalakya Tantra, \\ J.S.Ayurveda College, Nadiad.
}

\begin{abstract}
Pratishyaya (rhinosinusitis) is very difficult to treat as it happens with Sadhya Janak Nidana (sudden causative factor) also. Many times rapid and sudden onset is seen in Pratishyaya after exposure to even a weak causative factor. If this vicious cycle of Nidana (causative factor) and Roga (disease) continues and if treatment is neglected the Roga becomes Jeerna(chronic). At this stage it becomes necessary to cure the disease with Shodhana (purification) therapy rather Shaman (curative) therapy. In this type of chronic cases we can get good results with only Vamana Karma (emesis therapy). In modern medicine conservative management is the first choice and if the disease is not managed by it, they prefer surgery to maintain the drainage and ventilation of the sinuses. Vamana Karma with or without Nasya (nasal instillation) can give complete improvement in such cases. The burden and risks of surgery can be avoided and the quality of the patient's life can be improved with Ayurvedic treatment.
\end{abstract}

Keywords: JeernaVatika Pratishyaya, Vamana, Chronic rhinosinusitis JeernaVatika Pratishyaya, Vamana, Chronic rhinosinusitis .

\section{Introduction}

Pratishyaya (rhinosinusitis) is one of Nasa Roga (nasal disease), which is included in Urdhwa jatrugata Roga (diseases of head \& neck). (1) Among all Nasa Roga (nasal disease), Acharya Sushruta has mentioned Pratishyaya in separate Adhyay. (2) Thus he highlighted its extra importance. Even Acharya Charakrpani believes that Pratishyaya is the origin of all other nasal diseases.(3)There are five types of Pratishyaya mentioned by Acharya Sushruta-Vataja, Pittaja, Kaphaja, Raktaja and Sannipataja. Negligence of these types can lead to chronic stage i.e. Dushtal Jeerna Pratishayaya (chronic) and other complication like- Badhirya (deafness), Agnisada (loss of appetite) etc. (4) So it is very important to treat the disease timely in its acute stage. The common line of treatment is based upon the condition of the disease. All Pratishyaya except acute one should be treated with Sarpi Pana (ghee), Swedana (fomentation), Vamana (emesis) and Avapeeda Nasya (nasal instillation).(5) Pratishyaya can be correlated with rhinosinusitis in modern science.

*Corresponding Author:

\section{Kunjal H Bhatt}

Lecturer, Department of Shalakya Tantra,

J. S. Ayurveda College,

Nadiad.

E-mail ID: drkhbhatt@gmail.com

\section{Case study}

A 46 year old male patient, from Baroda, having complaints of Nasasrava (watery nasal discharge), Kshavathu (sneezing), Shirahshool (headache), Galshotha (sore throat), Netrashoola (pain in eyes) since last 15 years came to OPD of P. D. Patel Ayurveda Hospital \& J. S. Ayurveda college, Nadiad to take Ayurvedic medicine. Before coming to the institute the patient had gone to allopathy hospital and he was hospitalized for 2 days. He was advised CT scan of para nasal sinus (Dt-11/1/2017) which showed very minimal mucosal disease in right and left maxillary sinus; minimal mucosal disease in right ethmoidal sinus; totally opaque sinus filled with significant mucosal disease +/- retained secretions in Rt. sphenoid sinus and very minimal mucosal disease in left sphenoid sinus. $\mathrm{He}$ was advised surgery, but patient wanted to take Ayurvedic medicine. He came to the OPD on Dt-6/2/17

On examination the findings were as following:

- Nose- Deviated nasal septum towards left

- Right inferior turbinate hypertrophy Congestion

- Ears- Both ear canals were clear, Both tympanic membranes were intact and mild retracted

- Throat- Congestion was seen in posterior pharyngeal wall

On first visit (Dt-6/2/17) the patient was advised Vamana Karma but due to some unavoidable reasons, he refused admission and was given medicines as 
follows-

- Pathyadi Kwath (decoction) $-40 \mathrm{ml}$, twice a day

- Lakshmi Vilas Ras- 2 tab twice a day, for 14 days.

On second visit (Dt-18/2/17) the patient had improvement and he was advised the same medicine for 14 days.

The patient came for third time (Dt-24/2/17) for hospitalization and Vamana Karma. The patient was admitted and started Ghrita (ghee) Paana. The treatment given during hospitalization is as follows-

\begin{tabular}{|c|l|}
\hline Date & \multicolumn{1}{|c|}{ Treatment } \\
\hline $24 / 2 / 17$ & Snehapana- Plain Goghrita-40 $\mathrm{ml}^{* 2}$ \\
\hline $25 / 2 / 17$ & Snehapana- Plain Goghrita-60 $\mathrm{ml}^{* 2}$ \\
\hline $26 / 2 / 17$ & Snehapana- Plain Goghrita-80 $\mathrm{ml}^{* 2}$ \\
\hline $27 / 2 / 17$ & $\begin{array}{l}\text { Sarvang Abhyang (massage) with } \\
\text { Mahanarayana Taila } \\
\text { Sarvang Bashp swedana } \\
\text { (fomentation) with Nirgundi Patra }\end{array}$ \\
\hline $28 / 2 / 17$ & $\begin{array}{l}\text { Sarvang Abhyang with Mahanaraya- } \\
\text { na Taila } \\
\text { Sarvang Bashp swedana with } \\
\text { Nirgundi Patra } \\
\text { Vamana Karma-Madan Phala Majja } \\
\text { Churna-3.5 gm with Madhu Q.s. } \\
\text { Vairchanika Dhumapana after Va- } \\
\text { mana }\end{array}$ \\
\hline $1 / 3 / 17$ & $\begin{array}{l}\text { Samsarjana Krama (diet control) } \\
\text {-Peya }- \text { in evening }\end{array}$ \\
\hline $2 / 3 / 17$ & $\begin{array}{l}\text { Samsarjana Krama } \\
\text { Peya - in morning } \\
\text { Peya } \text { - in evening } \\
\text { Discharged (Advised to follow Sam- } \\
\text { sarjana Krama) }\end{array}$ \\
\hline
\end{tabular}

\section{Details of Vamana Karma:}

8 Vega were observed and Pittanta (with Aushadha) Vamana was observed.

\section{After treatment:}

At the time of discharge complete relief was observed in all the symptoms. He was advised

- Pathyadi Kwath-40ml, twice a day

- Lakshmi Vilas Ras- 2 tab twice a day, for 1 month and 10 days

With Pathya Palana (Do and don'ts) of Pratishyaya.

The CT scan was advised to rule out the sinusitis. On Dt.13/4/17 repeat CT scan was done which suggested normal sphenoid and frontal sinuses, minimal mucosal thickening at the base of both maxillary sinus.
Observation:

\begin{tabular}{|l|c|c|}
\hline \multicolumn{1}{|c|}{ Symptoms } & $\begin{array}{c}\text { Before } \\
\text { treatment }\end{array}$ & $\begin{array}{c}\text { After } \\
\text { treatment }\end{array}$ \\
\hline $\begin{array}{l}\text { Nasasrava } \\
\text { (Watery } \\
\text { discharge) }\end{array}$ & +++ & - \\
\hline Kshvathu (Sneezing) & ++ & - \\
\hline $\begin{array}{l}\text { Shirahshool } \\
\text { (Headache) }\end{array}$ & + & - \\
\hline $\begin{array}{l}\text { Galshotha (Sore } \\
\text { thoart) }\end{array}$ & + & - \\
\hline $\begin{array}{l}\text { Netrashoola (Pain in } \\
\text { eyes) }\end{array}$ & + & - \\
\hline
\end{tabular}

\begin{tabular}{|l|l|l|}
\hline CT scan PNS & \multicolumn{1}{|c|}{ Before } & \multicolumn{1}{|c|}{ After } \\
\hline $\begin{array}{l}\text { Right and Left } \\
\text { Maxillary }\end{array}$ & $\begin{array}{l}\text { Very minimal } \\
\text { mucosal } \\
\text { thickening }\end{array}$ & $\begin{array}{l}\text { Very minimal } \\
\text { mucosal } \\
\text { thickening at } \\
\text { base }\end{array}$ \\
\hline $\begin{array}{l}\text { Right and } \\
\text { LeftEthmoid }\end{array}$ & $\begin{array}{l}\text { Rt. side minimal } \\
\text { mucosal disease } \\
\text { Lt side -normal }\end{array}$ & $\begin{array}{l}\text { Rt. } \\
\text { minimal side } \\
\text { mucosal } \\
\text { disease Lt side } \\
\text {-normal }\end{array}$ \\
\hline $\begin{array}{l}\text { Right and } \\
\text { LeftFrontal }\end{array}$ & $\begin{array}{l}\text { Normal } \\
\text { Right and Left } \\
\text { Sphemoid }\end{array}$ & $\begin{array}{l}\text { Rt side totally } \\
\text { opaque sinus, } \\
\text { filled wormal with } \\
\text { significant } \\
\text { mucosal disease } \\
+/ \text { retained } \\
\text { secretions } \\
\text { Lt side -normal }\end{array}$ \\
\hline
\end{tabular}

\section{Disscusion}

Acharya Sushruta has mentioned that each Pratishyaya should be treated with Vamana Karma except acute stage; followed by Shirovirechaka Nasya. (6) In the Samprapti (pathogenesis) of the disease it is mentioned that the Dosha get accumulated in Shira pradesha (head) and when aggravated by various Nidana Sevana (causative factors); it cause Pratishyaya. (7) It is known as 'Chaya Purvak Prakopa'. In such conditions when the quantity of vitiated Dosha is more (Bahu Dosha Avastha), Shodhana Karma (purification) is required. (8) The selection process of Shodhana Karma depends upon the main site of the accumulated Doshas and their nearer route. In this case, Vamana was selected as no 
any other Karma works on vitiated Kapha Dosha as Vamana does. (9) Pratishyaya is an Urdhvajatrugata Roga (diseases of head and neck) and Shira (head) is the site of Kapha Dosha. (10) In addition to that while describing the benefits of Vamana Karma Acharya Charak has mentioned that Murdha (head) and indriya (sense organs) get purified with the help of Vamana Karma. (11) Hence Vamana Karma is indicated in Pratishyaya. Once Urdhva Kaya (upper body) Shodhana is achieved by Vamana then Shiro Virechana (purification of head) is done to remove the dosha from the Shir Pradesha with the help of Nasya to get complete relief. But in this patient he got complete symptomatic relief after Vamana Karma with Oral medicine and follow up CT scan report showed that totally opaque right sphenoid sinus was completely normal. In this case much difference was not observed in mucosal thickening of maxillary and ethmoid sinus, it may be as patient had not taken Nasya (nasal instillation) after Vamana (emesis). This mucosal thickening may resolve with Shirovirechaka Nasya.

In modern medicine the line of treatment of Rhinosinusitis is antibiotics, decongestant, antihistaminics (12) and if not relieved with medicines FESS (Functional Endoscopic Sinus Surgery) is suggested. With the Ayurvedic management patient can get relief from the disease and can skip the burden and risks of surgeries.

\section{Conclusion:}

In this case the patient was suffering from Jeerna Vatika Pratishyaya. With Vamana Karma (emesis therapy) only patient got complete relief from all the symptoms. After Vamana karma, for removal of residual dosha and for further prevention of recurrence Nasya (nasal instilattion) and dhumapana (medicated smoke inhalation) should be given in such patients (13). In chronic stage of Pratishyaya; Nasya should not be perform prior to shodhana karma (purification therapy). Nasya karma followed by vamana karma, provides much better and faster relief.

\section{Reference:}

1. Vaidya Yadavaji Trikamji, Acharya Sushruta, Shushruta samhita, Sutrasthana 1/7(2), print 2010, Varanasi : Chaukhambha surbharati prakashan ; page no.3.

2. Vaidya Yadavaji Trikamji, Acharya Sushruta, Shushruta samhita, Uttartantra24, print 2010, Varanasi : Chaukhambha surbharati prakashan ; page no. 651 .
3. Vaidya Yadavaji Trikamji, Charaka SamhitaChakrapanidatta, Chikitsa sthana 26/107, print 2009, Varanasi : Chaukhambha surbharati prakashan ; page no. 604.

4. Vaidya Yadavaji Trikamji, Acharya Sushruta, Shushruta samhita, Uttartantra 24/17, print 2010, Varanasi: Chaukhambha surbharati prakashan ; page no. 652 .

5. Vaidya Yadavaji Trikamji, Acharya Sushruta, Shushruta samhita, Uttartantra 24/18, print 2010, Varanasi : Chaukhambha surbharati prakashan; page no. 652 .

6. Vaidya Yadavaji Trikamji, Acharya Sushruta, Shushruta samhita, Uttartantra 24/18, print 2010, Varanasi: Chaukhambha surbharati prakashan; page no. 652.

7. Vaidya Yadavaji Trikamji, Acharya Sushruta, Shushruta samhita, Uttartantra 24/18, print 2010, Varanasi, Chaukhambha surbharati prakashan, page no.652

8. Vaidya Yadavaji Trikamji, Acharya Sushruta, Shushruta samhita, Uttartantra 24/18, print 2010, Varanasi, Chaukhambha surbharati prakashan, page no. 651

9. Vaidya Yadavaji Trikamji, Acharya Sushruta, Shushruta samhita, Uttartantra 24/18, print 2010, Varanasi, Chaukhambha surbharati prakashan; page no.652; Dalhan commentary on Su.Su.21/37, page no.652

10.Vaidya Yadavaji Trikamji, Agnivesha, Acharya Charaka, Charak Samhita, Sutrasthana,20/19, reprint 2009, Varanasi, Chaukhambha Surbharati Prakashan, page no. 115

11.Harisadasivashastri, Acharya Vagbhatt, Astanghridayam, Shutrasthana 12/3, print 2014, Varanasi, Chaukhamba Sanskrit Prakashana,, page no. 192

12.Vaidya Yadavaji Trikamji, Agnivesha, Charaka, commentory on Chakrapanidatta on Charaka Samhita. Siddhi sthana 1/15-16, Reprint ed.2009, Varanasi, Chaukhambha Surbharati Prakashan, page no.680

13.PL Dhingara, Shruti Dhingara,“ Diseases of ear nose \& throat", 5th edition,ELESVIER publication, 2010 chapter37,page 209

14.Kunjal H. Bhatt, Hemang U. Raghavani, Kishore G. Satani. Preventive, promotive and curative aspect of Dhumapana in Urdhvajatrugata Roga. J Ayurveda Integr Med Sci 2017;2:165-169. http:// dx.doi.org/10.21760/jaims.v2i2.7721. 